\title{
19
}

\section{The New Pacific Diplomacy and the South Pacific Tuna Treaty}

\section{Jope Tarai}

The shift to a new Pacific diplomacy, where the Pacific's agenda is no longer externally driven, but is to an extent led from within the Pacific, can be seen in the case of the negotiation of the South Pacific Tuna Treaty. ${ }^{1}$ To demonstrate this shift, this chapter will highlight the factors shaping the inception of the treaty, and those influencing the current negotiations. These include the regional agenda, the Pacific's leveraging capability, and the influence and roles of the regional institutions. It will highlight the role of the Forum Fisheries Agency (FFA) at the time the initial treaty was signed in 1987, and the role of the islandsonly Parties to the Nauru Agreement (PNA) in the contemporary era. This will demonstrate how the new Pacific diplomacy has been instrumental in elevating the Pacific's negotiating position.

1 The South Pacific Tuna Treaty is officially known as the Treaty on Fisheries between Governments of certain Pacific Island States and the Government of the United States of America. 


\section{Negotiating the Original South Pacific Tuna Treaty}

The South Pacific Tuna Treaty was signed in 1987 and came into force in June 1988 (Chang 2007). The treaty is a multilateral agreement that brings together a total of 16 Pacific countries with the United States of America. ${ }^{2}$ It allows for a maximum of 50 purse seine vessels to be licensed. Initially, it had guaranteed a total of US\$12 million per year, for a total of five years, spanning an initial period of 1988-1993 (Glebbeek 1990). This payment combined a majority of US government funding with a smaller portion paid by industry. Of the agreed financial package of US\$60 million over the first five-year period, 85 per cent was allocated to countries according to catch volume within the various Exclusive Economic Zones (EEZs) of participating countries. The remaining 15 per cent was apportioned equally among all parties, irrespective of catch, in the form of project aid and technical assistance.
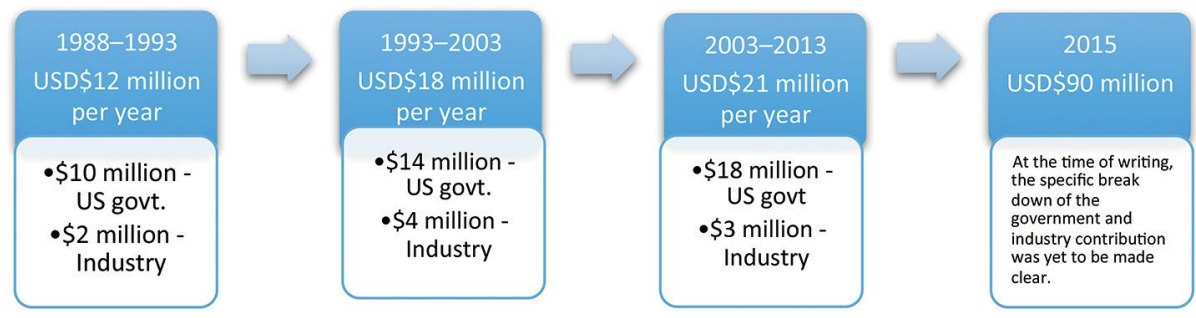

\section{Figure 19.1: The South Pacific Tuna Treaty}

Source: Author's research.

The original settlement of the treaty had not been without controversy. In the early 1980s, this was mainly attributed to the conflicting interpretations of the United Nations Convention on the Law of the Sea (UNCLOS) 3 of 1982 (Maw 1983; Lugar 2004; Kengalu 1988). The US refused to recognise coastal state claims to tuna stocks as highly migratory species within their EEZs (Malone 1983). This led to the Pacific's so-called 'Tuna Wars', which saw a number of US vessels confiscated by Pacific states, leading to retaliatory US trade embargoes, including the infamous Jeanette Diana and Danica debacles (Kengalu 1988; Gubon 1987). ${ }^{4}$

\footnotetext{
2 The 16 countries include: Australia, Cook Islands, Federated States of Micronesia, Fiji, Kiribati, Marshall Islands, Nauru, New Zealand, Niue, Palau, Papua New Guinea, Samoa, Solomon Islands, Tonga, Tuvalu, and Vanuatu.

3 The coastal states took Article 61 and Article 64 of the UNCLOS to claim jurisdiction over highly migratory species (tuna), while the US disregarded this claim, which fuelled much of the contentious interpretation between the two sides.

4 The Solomon Islands government seized the US vessel Jeanette Diana in June 1984 after it was caught illegally fishing within the Solomon Island's Exclusive Economic Zone (EEZ). The US fishing vessel Danica was confiscated by the government of Papua New Guinea in February 1982 for illegally fishing within PNG's EEZ.
} 
Despite these tensions and differences, when the treaty was concluded, the Pacific was able to secure significant financial returns, through access fees, and a degree of recognition of ownership over migratory species within its EEZs. The treaty was outstanding at the time because it was able to accrue a 10 per cent rate of return compared to the 3 per cent average for bilateral access agreements, while providing the FFA comprehensive effort and catch data (Tarte 1998).

The difference in the interpretation of the UNCLOS, and the Pacific's push for the US to recognise their claim to highly migratory species within their EEZs, was the main agenda for the Pacific at this time. Pacific Island states, like other coastal states, were adamant in their claim over highly migratory resources. Ultimately, this claim would allow the Pacific states to derive financial returns from access fees and benefits through cooperative engagements with distant water fishing nations (Gubon 1987).

However, it is instructive to note that this agenda was externally motivated, rather than internally initiated. The agenda was more a response to the US policy of non-recognition, which indicated that the modus operandi of Pacific diplomacy at the time was more reactive to external influences. It developed as an attempt to mediate the uncompromising position of the US. While the UNCLOS did provide a basis for the assertion of jurisdictional claim for the Pacific, it was in essence an external leverage.

The looming presence of the Soviet Union, at least in the mind of western powers, provided an additional leverage for the Pacific during the diplomatic tensions with the US in the 1980s. Kiribati seized their opportunity and secured a fishing agreement with the Soviet Union in 1985, with keen interest shown by Vanuatu and varying other Pacific states (Dora 1985). This engagement with the Soviet Union motivated the US to negotiate a multilateral agreement that, to an extent, conceded to the Pacific's demands (Dora 1985; Gubon 1987; Doulman 1986). The security and power balancing concerns brought on by the Soviet presence were too great for the US to ignore (Lugar 2004). This creatively produced the 'Pacific's Leverage' which enabled the Pacific to bargain with unprecedented effect. The Pacific was well aware of how much power and impact the Soviet engagement had on the US. Proof of this was seen in the early 1980s. In a blunt response to the United States, at the height of its diplomatic tensions, the Solomon Islands threatened to engage the Soviet Union directly (Gubon 1987). Such diplomatic démarche can be termed the 'Alternate Leverage Strategy' to asserting Article 64 of the UNCLOS, and the universality of international law. The Tuna Wars proved the latter to be a weak bargaining point for the Pacific, leading to substantive losses from sanctions and embargoes imposed by the US. Playing off the strategic interests of the US and the Soviet Union provided more effective leverage for the Pacific, which not only pressured the US into concessions but also elevated the power of the Pacific. 
There is no denying that the Pacific successfully utilised this leverage to its best possible extent, however it was still subject to the continued competition between the US and the Soviet Union. As a result, basing the bargaining power of the Pacific on this strategic competition was only useful until the Soviet Union's demise in the late 1980s. This also indicated that Pacific diplomacy at the time was more reactive to external influences. Such reactive approaches provided insufficient space for the Pacific to take full ownership of its agenda. For instance, there was no leverage available during the second period of the South Pacific Tuna Treaty, from 1993 to 2003, to enable the Pacific to bargain for a substantive increase in the financial returns paid by the US. Despite the fact that the value of the fishery had already begun to rise, the Pacific was locked into a 10 -year deal of having to distribute US $\$ 18$ million amongst 16 countries (Aqorau 2014).

The establishment of the FFA and its links with the UNCLOS reveals two key motivations of Pacific diplomacy at the time. One was the Pacific's assertion of ownership over the fish stocks, which was expressed in a united position in the UNCLOS - conforming to the position of coastal states against states such as the United States, which disputed the interpretation of Articles 61 and 64 of the UNCLOS. A second motivation was the economic and financial opportunities made available through the fishery. The FFA's representative force was premised on the fact that it comprised all the Pacific Island states. As such, it was able to represent the Pacific's collective position in regard to the UNCLOS. Through the tuna treaty, the FFA administered financial returns to the Pacific states with various other technical benefits.

The FFA's primary function was to help manage fisheries resources within the Pacific EEZs while seeking to maximise returns from access agreements (Tamate 2003; Tarte 2007). The FFA served to safeguard the Pacific's interests, considering the inherent institutional, diplomatic and technical constraints of the Pacific. The FFA helped focus the Pacific's efforts on the collective agenda, which effectively mediated the Distant Water Fishing Nations (DWFN) 'divide and conquer' strategy of playing Pacific states off with one another (Doulman 1988).

The utility of FFA's assistance to the Pacific was evident when DWFNs cited reservations in negotiating with Pacific states assisted by the FFA. DWFNs stated that negotiations were bilateral and only required the two states concerned without FFA assistance (Doulman 1988). This demonstrated that the DWFNs were recognising the strength of FFA as a galvanising force.

In characterising the Pacific's diplomacy at the time, we can see that the FFA provided important institutional leverage for the island states which enhanced the Pacific's negotiating position and capability. The emergence of UNCLOS led 
to the Pacific assertion of jurisdiction over its fishery and resource. It created a sense of resource ownership by the Pacific. The establishment of an institutional basis for Pacific representation harnessed the collective leveraging capabilities in negotiations with DWFN (Rayfuse 2004). Such an approach was necessary due to the overpowering influence of the DWFNs in seeking to maximise their profits from exploitation of the fishery.

\section{Negotiating a new Tuna Treaty}

The last ten-year agreement of the tuna treaty, spanning 2003-2013, was criticised by Pacific countries for its rigidity. This criticism mostly came from the PNA states ${ }^{5}$ which had a larger stake in the fishery, since most of the tuna that was caught in their collective EEZs. On the other hand, the non-PNA states ${ }^{6}$ were more comfortable with the status quo because, for very little to no effort, they would still be getting some return from the treaty (Aquora 2014). It became clear that the value of the US tuna treaty, particularly to those countries where US tuna vessels mainly operated, was grossly inadequate. This was evident when the fishery's estimated value rose to US\$7 billion (Johnson 2013) and the US vessels, through access provided by the treaty, would catch an estimated US $\$ 500$ million worth of tuna (Aqorau 2014). The effort on the part of some Pacific countries to pursue bilateral deals outside of the treaty was understandable.

The negotiations for the renewal of the South Pacific Tuna Treaty began in 2009 (Ruaia 2014) and at the time of writing are ongoing. The frustrations of the Pacific were expressed mostly by the states with the most purse seining activity, namely the PNA states. This stemmed from the static nature of the tuna treaty and the increasing financial incentives outside of the treaty. Since the US vessels, through the treaty, are paying a markedly lower price for access compared to other foreign DWFNs (Norris 2013; Aqorau 2014), the Pacific's ability to fully maximise financial returns from the resource is undermined. The treaty also created exemptions for US vessels which undercut conservation efforts focused on the fishery. This has been through the terms and conditions within the tuna treaty which provide immunity from requirements in licensing arrangements (Dunn et al. 2006).

The Pacific's agenda has gravitated around resolving this challenge and a range of related issues. These include the financial returns from the treaty, the full application of national laws, and the acceptance of conservation measures by

5 The Parties to the Nauru Agreement are the tuna-rich states of Federated States of Micronesia, Kiribati, Marshall Islands, Nauru, Palau, Papua New Guinea, Solomon Islands, and Tuvalu.

6 The non-PNA states are the other states in the Pacific Islands Forum Fisheries Agency (FFA), including Australia, Cook Islands, Fiji, New Zealand, Niue, Samoa, Tonga, and Vanuatu. 
the US. While details of the full application of national laws and conservation measures are still to be determined, the significant expansion of the financial returns in recent years reflects a notable development for the new Pacific diplomacy.

Considering the massive value of the fishery and the lucrative incentives in bilateral deals outside the treaty, the Pacific began to push for a much higher financial return. It was evident that US\$21 million was no longer an acceptable rate of return for the Pacific states. This became clearer as statistics revealed that on a daily rate the US fees provide for US $\$ 330$ compared to the Japanese access fee to the Pacific of US\$3,560 per day in 2011 (Pala 2011). In the negotiations which began in 2009, the initial talks were mostly focused on the financial returns (Roosen 2013). In 2011, the US offered to increase the rate of return to from US $\$ 21$ million to US $\$ 42$ million (Aquora 2014). However, this was not well received by the Pacific states, since it was still considered to be insufficient. Additionally, the US chief negotiator had threatened that the US would end all development aid to the region if the Pacific did not agree with the US position (Pala 2011). As a result, in April 2011, Papua New Guinea's acting Prime Minister Sam Abal announced:

We formally give notice to withdraw from the Multilateral Treaty on Fisheries with the US ... This hard line stance by PNG on behalf of smaller Pacific Island countries is set to send direct signals to Washington that the Multilateral Fish Treaty is unsustainable. This is your time, US, to recognize island countries and increase license fees for fishing. The PNG Government's decision is the right thing for the nations in the region. It is about time our friends state clearly and fairly their interest with us. They must give credit where it is due (Hriehwazi 2011).

This statement challenged the US directly because a withdrawal by Papua New Guinea (PNG) would end the existence of the treaty itself. The treaty stipulates that in a situation where the United States, Kiribati, Federated States of Micronesia, or PNG formally withdraw from the treaty, the treaty becomes non-existent (Ruaia 2014). In February 2012, the US offered US $\$ 45$ million to the Pacific Island parties, aimed at persuading PNG to rescind its application for withdrawal and termination of the treaty (Islands Business 2012). The Pacific had been demanding US $\$ 60$ million for 7,000 days, while the US was offering US $\$ 58$ million for 9,000 days of access (Larsen 2012). The negotiations then developed to a point where the US was willing to accept 8,300 days for US $\$ 63$ million (Matau 2012). After a transitional agreement of 18 months to allow time for the extension of negotiations, the US offered the Pacific US\$94.5 million (Ruaia 2014). By late 2014, the US had agreed to pay US $\$ 90$ million, with 8,300 days, for a period of 12 months, for the year 2015 (FFA 2014). While this amount represents a substantial increase over previous offers, negotiations are still ongoing to fully resolve the various demands of the Pacific countries. 
In assessing the recent negotiations, it is clear that the Pacific's bargaining power has substantially increased. This bargaining power has been fortified through internal and external sources of leverage. An external leverage for the Pacific in this regard is the looming presence of China in the region, which provides an opportunity for engagement against the US. Simultaneously, the leverage originating within the Pacific, is the PNA Vessel Day Scheme (VDS), which has elevated and bolstered the Pacific's negotiating position.

The US presence within the South Pacific had been on the decline since the Cold War, until 2007, which was labelled as the 'Year of the Pacific' (Rice 2007). This marked an attempt to invigorate American presence in the South Pacific. The gradual decline was witnessed through the withdrawal of the US Agency for International Development office from Suva and the diplomatic mission in Solomon Islands during the 1990s, coupled with a reduction in high-level engagement with the Pacific Island leaders (McAslan 2013). The US tuna treaty remained the somewhat lone symbol of US commitment to the South Pacific. The treaty was able to provide the US with a multifaceted level of engagement with 16 countries, 14 of which were Pacific Island countries. The multifaceted nature of the treaty not only served the US fisheries interests but also diplomatic, political and geostrategic interests. However, while US presence had begun to decline, Chinese engagement in the region had begun to increase. This was evidenced in the export and import figures in Pacific Island trade, where the US accounted for only 2.2 per cent, while China grew to 4.1 per cent (McAslan 2013). Additionally, China has begun to emerge as a significant aid donor in the Pacific, diversifying its assistance and support (Herr and Bergin 2011). This growing engagement has worried Washington, with former United States Secretary of State Hillary Clinton stating to the US Senate Foreign Relations Committee in 2011:

We are in a competition with China ... They have brought all of the leaders of these small Pacific nations to Beijing, wined them and dined them. I mean, if anybody thinks that our retreating on these issues is somehow going to be irrelevant to the maintenance of our leadership in a world where we are competing with China that is a mistaken notion (Quinn 2011).

Similar to the role of the Soviet Union in the 1980s, China's looming presence has appeared to become a source of external political leverage for the Pacific states. In amongst the international agreements, laws and regimes, major power rivalry provides a useful opportunity for the Pacific. This was evident in late 2014 when the US offered US $\$ 90$ million for 8,300 fishing days for 2015, which was agreed amongst the Pacific states. But Kiribati withdrew a portion of its days offered in the 8,300 days pool, to offer to Asian states, which were alleged to have been Taiwan and China (Field 2014). Kiribati has a lot more to gain from engaging outside the treaty, considering it has an extensive EEZ and tuna catch 
capacity. Once again, the weakened financial incentive in the treaty for states that can claim a larger return, such as Kiribati, was revealed in such an incident. What can be categorised as an economic and financially motivated decision, has provided a perceived political outcome, towards the evident competition for influence in the region, between the US and China.

The crucial role played by the PNA underpins the internal leverage of the Pacific. The PNA constitutes the tuna-rich states of Federated States of Micronesia, Kiribati, Marshall Islands, Nauru, Palau, PNG, Solomon Islands, and Tuvalu (Tamate 2014; PNA 2013). This region is where US purse seine activity is concentrated. The PNA's sub-regional role has provided an important basis for the bargaining power of the Pacific states in the treaty. This is in large measure attributed to the VDS adopted by the PNA. The VDS is a rights-based management mechanism, which was designed by PNA to move to licensing purse seiners on the basis of number of fishing days as opposed to vessel numbers, as was the strategy under the Palau Arrangement (Havice 2010). This means that vessels have to purchase days to fish within waters of the PNA states. It was developed to limit vessel numbers creating competition amongst DWFN, and enabling higher rates of return for the PNA states. The VDS was developed over four years, from 2000-2004, and it went into its implementation stages in 2005 (Aqorau 2009). So far it has more than proven its benefit to the PNA states. In 2010, through the hard limits enforced by the VDS, the revenue gained by PNA rose to US\$60 million, then US\$104 million in 2011, US\$229 million in 2012 and was projected to be US\$249 million in 2013 (Aqorau 2014).

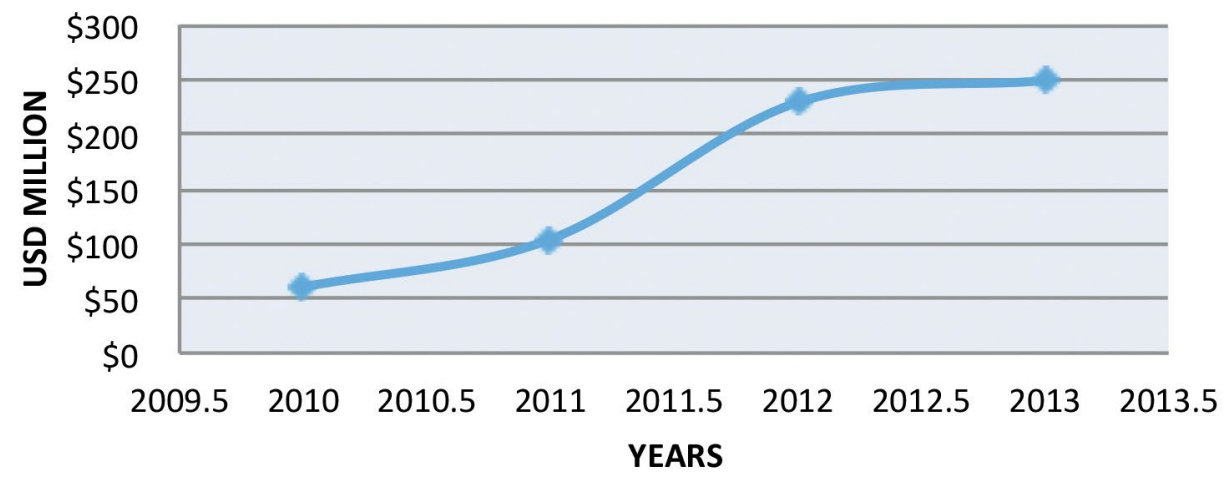

Figure 19.2: PNA revenue from access

Source: Adapted from Aqorau (2014a).

Apart from the substantive financial returns, the VDS finally gave the Pacific states control over their resource, which translated into bargaining and negotiating power. The authority to set the benchmark price on fishing days swung the power balance in favour of the Pacific states. 
The VDS is an internally instigated leveraging tool for the resource owners, which has fundamentally transformed the Pacific's negotiating position. It is unprecedented by being a mechanism owned and driven from within the Pacific, and is a crucial marker of the new Pacific diplomacy. The design, manufacture and ownership of VDS as an instrument for, of and by the Pacific, is a testament of the new-found power in negotiation that is internally motivated and controlled.

The combination of the internal and external leveraging exercised by the Pacific has elevated its influence in the negotiations with the US, as witnessed by the rising financial returns accrued during the treaty negotiations since 2009. At the time of writing, the other outstanding issues, such as the full application of national laws and conservation measures, were yet to be finalised. However, considering the external and internal leverage available to the Pacific states, it can be expected the remaining outstanding issues will be resolved in the Pacific's favour.

Clearly, the Pacific has been 'flexing its muscles' (Islands Business 2012) and continues to do so with what now appears to be a combination of internal and external sources of leverage. The new Pacific diplomacy, as evident in the South Pacific Tuna Treaty's negotiation with its emphasis on a regionallyowned and controlled diplomacy, has the potential to increase the power of the Pacific in global negotiations. Resource specific sub-regional groups, such as PNA, using a mechanism such as the VDS, elevate the control, ownership and bargaining capacity of the Pacific states. This is aided by external sources of leveraging, such as the looming presence of China, which compels the US to seek an agreement with the Pacific states. A combination of internal control and overarching geopolitical competition has proved advantageous for the Pacific's new diplomacy as seen in the tuna sector.

\section{References}

Aqorau, T., 2009, 'Recent Developments in Pacific Tuna Fisheries: The Palau Arrangement and the Vessel Day Scheme', The International Journal of Marine and Coastal Law 24(3), pp. 557-81.

Aqorau, T., 2014a, 'Reshaping International Fisheries Development: Assimilating the treaty on fisheries between the governments of certain pacific island states and the United States under the PNA Vessel Day Scheme (VDS)', International Journal of Marine and Coastal Law 29(1), pp. 52-76.

Aquora, T., 2014b, personal communication, November. 
Chang, K.L., 2007, A Sustainable Fishery Management Study: The yellowfin tuna fishery in the Western Central Pacific Ocean, ProQuest Information and Learning Company, Salt Lake City.

Dora, A., 1985, The South Pacific Islands: New focus needed for U.S. policy, The Heritage Foundation, Washington.

Doulman, D.J., 1986, Some Aspects and Issues Concerning The Kiribati/Soviet Union Fishing Agreement, East-West Center, Honolulu.

Doulman, D.J., 1988, 'In Pursuit of Fisheries Cooperation: The South Pacific Forum Fisheries Agency', University of Hawaii Law Review 10(1), pp. 138-50.

Dunn, S., L. Rodwell and G. Joseph, 2006, 'The Palau Arrangement for the Management of the Western Pacific Purse Seine Fishery', presentation at Sharing the Fish Conference, Forum Fisheries Agency, Fremantle.

FFA, 2014, 'Pacific Strikes US90m Tuna Deal for US Treaty in 2015, FFA Applauds Pacific Negotiations', Pacific Islands Forum Fisheries Agency. Available at: www.ffa.int/node/881.

Field, M., 2014, 'Kiribati Deal Shocks Fishing World', stuff.co.nz. Available at: $\quad$ www.stuff.co.nz/business/industries/10603447/Kiribati-deal-shocksfishing-world.

Glebbeek, P., 1990, 'South Pacific Nuclear Free Zone Treaty: A lost battle against the superpowers?' Available at: repub.eur.nl/pub/18836/wp73.pdf.

Gubon, F., 1987, The 1987 Pacific Island States/United States Fisheries Treaty and its Implications for Fisheries Development, Management and Conservation in the South Pacific Islands Region, University Of Washington, Seattle.

Havice, E., 2010, 'The Structure of Tuna Access Agreements in the Western and Central Pacific', Marine Policy 34(5), pp. 979-87.

Herr, R. and A. Bergin, 2011, Our Near Abroad: Australia and Pacific islands regionalism, Australian Strategic Policy Institute. Available at: archives. pireport.org/archive/2011/December/Our_near_abroad.pdf.

Hriehwazi, Y., 2011, 'PNG Tells Mighty US To Go Jump', Atuna. Available at: www.atuna.com/NewsArchive/ViewArticle.asp?ID=9501.

Islands Business, 2012, 'Pacific Islands Flexing Muscles?'. Available at: www. islandsbusiness.com/2012/2/fisheries/pacific-islands-flexing-muscles/. 
Johnson, G., 2013, 'Tuna Showdown: Pacific tuna stock faces growing crisis of inaction', Islands Business. Available at: www.islandsbusiness.com/2013/11/ cover-story/tuna-showdown/.

Kengalu, A.M., 1988, Embargo: The Jeanette Diana affair, Robert Brown and Associates, Bathurst.

Larsen, E., 2012, 'Fish and Foreign Policy: Renegotiating the South Pacific Tuna Treaty', cogitASIA, 26 March. Available at: cogitasia.com/fish-and-foreignpolicy-renegotiating-the-south-pacific-tuna-treaty/.

Lugar, R., 2004, 'United Nations Convention on the Law of the Sea: Senate Executive Report', US Government Printing Office, Washington.

Malone, J.L., 1983, 'The United States and the Law of the Sea after UNCLOS III', Law and Contemporary Problems 46 (2), pp. 29-36.

Matau, R., 2012, 'Unite for Tuna', Islands Business. Available at: www. islandsbusiness.com/2012/10/interview/unite-for-tuna/.

Maw, C.E., 1983, 'The United States and the Law of the Sea after UNCLOS III: Comment', Law and Contemporary Problems 46(2), pp. 55-60.

McAslan, H.R., 2013, China's Increasing Influence in Oceania: Implications for the United States, United States Government, Philadelphia.

Norris, W., 2013, 'Issues of the South Pacific Tuna Treaty', personal communication.

Pala, C., 2011, 'Islands Revoke US Fish Treaty', Islands Business, Suva.

Parties to the Nauru Agreement (PNA), 2013, 'Parties to the Nauru Agreement: About us'. Available at: www.pnatuna.com/About-Us.

Quinn, A., 2011, 'Clinton Says China Seeks to Outflank Exxon in Papua New Guinea', Reuters, 2 March. Available at: www.reuters.com/article/201 1/03/02/ us-china-usa-clinton-idUSTRE7215UV20110302.

Rayfuse, R.G., 2004, Non-Flag State Enforcement in High Seas Fisheries, Martinus Nijhoff Publishers, Netherlands.

Rice, C., 2007, 'Eighth Pacific Island Conference of Leaders', US Department of State Archive. Available at: 2001-2009.state.gov/secretary/rm/2007/ may/84414.htm.

Roosen, M.T., 2013, 'Outstanding Treaty Issues', personal communication. 
Ruaia, K., 2014, 'The South Pacific Tuna Treaty', personal communication, 1 May.

Tamate, J., 2004, 'Access Agreements: South Pacific Forum Fisheries Agency', FAO Corporate Document Repository, Fisheries and Aquaculture Department. Available at: www.fao.org/docrep/007/y5718e/y5718e07.htm.

Tamate, J., 2014, 'Regionalism: The experience of the Parties to the Nauru Agreement', SSGM, The Australian National University. Available at: ips. cap.anu.edu.au/sites/default/files/SSGM\%20IB\%202014_31.pdf.

Tarte, S., 1998, 'Regional Strategies: The Pacific Islands and Japan', The Journal Of Pacific Studies 22, pp. 159-72.

Tarte, S., 2007, 'Managing Tuna Fisheries in the Pacific: A regional success story', in J. Bryant-Tokalau and I. Frazer (eds), Redefining the Pacific?: Regionalism past, present and future, Ashgate Publishing, London, pp. 89-100. 
This text is taken from The New Pacific Diplomacy, edited by Greg Fry and Sandra Tarte, published 2015 by ANU Press, The Australian National University, Canberra, Australia. 